\title{
POLITICS, DEVELOPMENT STRATEGY, AND FAMILY PLANNING PROGRAMS IN INDIA AND PAKISTAN
}

JASON L. FINKLE

University of Michigan

The search for an answer to why some nations develop, modernize, and enjoy rapid economic growth while other nations lag behind or even decline is the most classic and recurrent issue confronting students of development. Without disregard for the significant theoretical contributions this enigma has elicited from social scientists, there may still be merit in a more modest and incremental approach to the problem. Instead of framing the question in terms of why some nations "take off" while others do not, an understanding of development may be equally advanced by asking why country A did better than country B in implementing a specific program. The answer may not produce such theoretical constructs as "need for achievement," "withdrawal of status respect," and "stages of economic growth," but it does direct attention to fundamental issues and building blocks of

AUTHOR'S NOTE: Many of the ideas contained in this paper were first presented by the author at the Conference on Political Science in Population Studies held at Chapel Hill, North Carolina, in 1970, and subsequently, at the April 1971 meeting of the Comparative Administration Group of the American Society for Public Administration in 
the development process that are often slighted in the quest for holistic explanations (see McClelland, 1961; Hagen, 1962; Rostow, 1960).

The primary objective of the present paper is to compare and analyze the organized government efforts by India and Pakistan to curtail population growth through family planning programs (for a useful comparison of agricultural programs in India and Pakistan which attempts to analyze and explain performance differentials in another field, see Falcon and Gotsch, 1968). The analysis will attempt to indicate the properties of each country's political system and development strategy that qualitatively influence program performance in family planning. Implicit in this analysis is the view that the effective implementation of a development program depends in large measure on nonprogrammatic variables external to the specific organization charged with responsibility for program management. The major points made within the paper are: (1) Pakistan has been relatively more effective in implementing its family planning program than has India; (2) the higher rate of family planning acceptance in Pakistan cannot be explained satisfactorily in terms of the sociological-demographic characteristics of the two populations; (3) the differential in family planning performance between the countries is more directly a

Syracuse, New York. Research for this publication was supported in part by funds provided by the U.S. Agency for International Development's 211(D) Grant (CSD-2171) to the Center for Population Planning. University of Michigan. The viewpoints expressed herein are those of the author and do not necessarily represent those of the Agency for International Development.

$I$ wish to acknowledge the advice and assistance of Mr. Gene Weiss and Mr. Timothy Johnson, both of the University of Michigan Center for Population Planning, whose knowledge and familiarity with the Indian and Pakistani Family Planning Programs proved consistently helpful in the formulation of this paper. Mrs. Barbara Crane and Miss Jane Hill were also helpful in their criticisms and assistance in the preparation of the manuscript. 
consequence of a combination of administrative and political factors which are also related to each country's economic policies and political system; and (4) the political and administrative characteristics which enabled Pakistan to carry out its family planning program more effectively were also properties of Pakistan's political system, which contributed to the forced resignation of President Ayub in March 1969, and to the political chaos that followed.

\section{THE INTRODUCTION OF FAMILY PLANNING IN INDIA AND PAKISTAN}

In 1951, India acquired the distinction of being the first nation in the world to adopt an official family planning policy aimed at reducing the rate of population growth through fertility control. While family planning was being encouraged by voluntary associations in Pakistan during the 1950s, it was not until 1960-almost a decade after Indiathat the government of Pakistan made fertility control a matter of public policy. Despite the relatively early commitment of the two governments to family planning, both nations only began to translate earlier policy pronouncements into serious programmatic activities in 1965, when a series of economic, international, and technological developments converged to provide a new impetus to family planning.

Developing nations became aware early in the 1960s that the period optimistically labeled the "development decade" would constitute, at best, ten years of modest economic growth and even more modest growth in per capita GNP. The burden of supporting a population growing at a rate of about $2.5 \%$ a year required that a significant portion of GNP be divered from investment and social development to meet the needs of population increase. Even a significant annual increase in GNP, as Pakistan achieved in the mid-1960s, became far less impressive when translated into per capita GNP. Moreover, the rate of population growth in India and 
Pakistan turned out to be higher than either country had expected. The results of the Indian census of 1961 produced great concern among planners, because it indicated that during the ten preceding years population growth was 30 million more than had been expected (Simmons, 1971: 181). In Pakistan, official population growth estimates based on the 1961 census appear significantly understated when contrasted with the findings of several subsequent studies in which population growth data were gathered with greater care (Bean, 1971; Hardee and Satterthwaite, 1970: $1-2)$.

It was clear that India and Pakistan had a population problem; yet, the presence of a problem may have little to do with whether the political machinery of that society recognizes and responds to the problem. In the mid-1960s, however, both India and Pakistan had competent personnel occupying high government positions who recognized the implications of the demographic trend in their countries and, more important, who had access to the centers of political power and decision-making if they were not decision makers themselves. These included the leaders of the Planning Commissions in both countries. as well as a number of senior administrators and technicians in ministries directly concerned with development.

Those in India and Pakistan who were stressing the importance of population as a factor in economic development received help for their cause from another direction in 1965. By then, international agencies and donor countries were evincing concern over the efforts of India and Pakistan in the family planning field. Foreign and international agencies began urging the two countries to devote greater resources to curtailing fertility and indicated their willingness to provide technical and financial assistance to that end (Lewis, 1970). ${ }^{2}$ Adoption and implementation of a family planning program were being viewed internationally as a prime indicator of each country's commitment and capacity to face up to the tough obstacles of development. 
In addition to a heightened awareness of the economic costs of population growth, the role of planners and technical experts in influencing policy, and international concern, if not pressure, to encourage government action, no development was more significant in making 1965 the landmark year for family planning than the introduction of a new contraceptive technology known as the intrauterine contraceptive device (IUD). For years, those concerned with rapid population growth and the need for family planning had been looking for a contraceptive that was easily administered, inexpensive, reversible, and medically safe, and that did not require daily or repeated action on the part of the user (Balfour, 1962). Many believed the IUD possessed more of the characteristics of an ideal contraceptive than any method previously available. It was regarded as particularly appropriate for the developing nations, where the lack of medical personnel and distribution systems and weak motivation on the part of potential users magnified the liabilities of the conventional contraceptives which had been the mainstay of their early family planning clinics. ${ }^{3}$

Prior to its adoption by the Indian and Pakistani family planning programs, the IUD has been tried on an experimental basis in numerous countries. The extensive reports and statistical analyses of its effectiveness, acceptance, and side effects were favorable (Segal et al., 1964). ${ }^{4}$ Although a more cautious and judicious analysis of this trial program indicates that the IUD is somewhat less than the "ideal" contraceptive and possesses its own inherent liabilities, family planning leaders, including medical doctors, were prone to gloss over the deficiencies of the IUD and to overstate its positive qualities.

The initial enthusiasm and optimism that accompanied this innovation in contraceptive technology has had enduring organizational implications for the population programs of India and Pakistan. For the first time, the two countries approached the population question confident that appro- 
priate technology was available for their own societies. They reacted by setting ambitious goals of fertility reduction, by making population policy a prominent feature of their development goals, and by increasing the size, resources, and even the authority of their family planning organizations.

When it was later realized that the IUD was not the ideal contraceptive that would enable the two countries to sharply curtail fertility rates in a matter of years. each country was in a sense saddled with its own policy pronouncements, publicized goals, and family planning organizations. It was now too late to withdraw gracefully from these commitments. Each country, therefore, had to pursue its own goals with imperfect contraceptive technologies. India had never relied exclusively on the IUD, not because of Indian prescience but because of the difficulty of making a decision that would apply uniformly throughout India. While Pakistan relied exclusively on the IUD for several years, by 1968 it was stressing sterilization as well. Ironically, if it had not been for the unreal expectations attributed to the IUD, neither country probably would have vested the resources and manpower in family planning that it did in 1965. Thus, large-scale family planning programs got under way in each country in 1965, though by 1970 evidence was mounting that Pakistan had been significantly more effective than India in implementing its program.

\section{COMPARATIVE PROGRAM PERFORMANCE}

Prior to an examination of why the two national programs differed in their performance, it is appropriate to consider the question of whether a differential actually existed. Serious and legitimate questions have been raised about the reliability of performance data in both countries (see, e.g., Bean, 1971); moreover, even if the reports on insertions of IUDs and sterilization operations were accurate, these are at best only a crude indication of program effectiveness. Without 
information about the age, parity, and prior contraceptive practices of the adopter, as well as the retention rates of the IUD, it is impossible to accurately assess the demographic effectiveness of a family planning program in preventing births or reducing the fertility rates (for a further discussion of the problems of evaluating family planning programs, see Berelson, 1969; Seltzer, 1970). In the absence of reliable data for these variables on a nationwide basis, the present analysis had had to rely upon what may be designated as intermediate indicators-the number of reported IUD insertions and sterilization operations performed.

As a criterion of relative administrative effectiveness, however, this measure seems justifiable, for the major organizational efforts of both programs in the years under examination have been aimed at the dissemination of these two contraceptive techniques. Further, the fragmentary evidence that exists concerning the demographic effectiveness of the two programs as well as the opinions of those who have observed both programs firsthand do not challenge the appropriateness of the intermediate indicators as being roughly representative of the relative accomplishments of India and Pakistan in family planning. ${ }^{5}$

The comparison of the two programs shown in Figures 1 and 2 is based on the cumulative number of IUD insertions and sterilization operations standardized to a rate per 1,000 total population for each country. As indicated graphically in Figure 1, India first introduced the IUD into its family planning program in early 1965. After a promising start, the Indian program leveled off and soon began to decline. Peak monthly performance for IUD acceptance occurred from October 1965 to March 1966, during which time an average of about 100,000 insertions took place each month. Since then, however, the IUD adoption rate has gradually but consistently gone down, and by 1970 the monthly average was about 40,000 insertions. The cumulative rate reached only 6.2 insertions per 1,000 by April 1970 . 


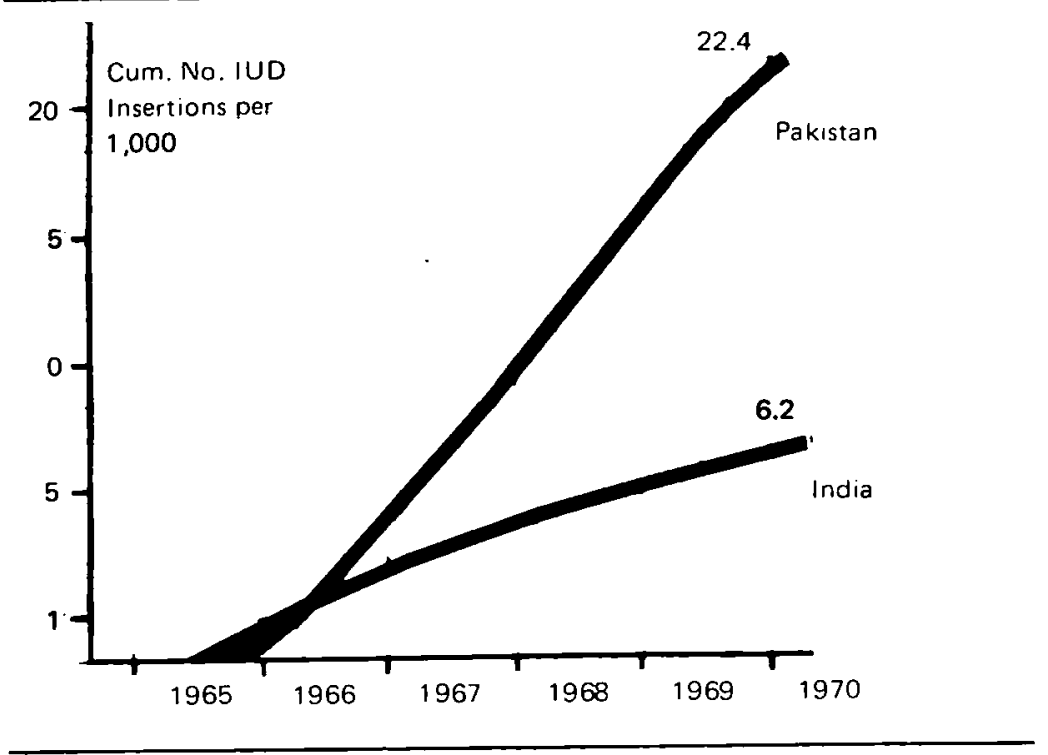

Figure 1: CUMULATIVE NUMBER OF IUD INSERTIONS PER 1,000 POPULATION ${ }^{2}$ INDIA AND PAKISTAN

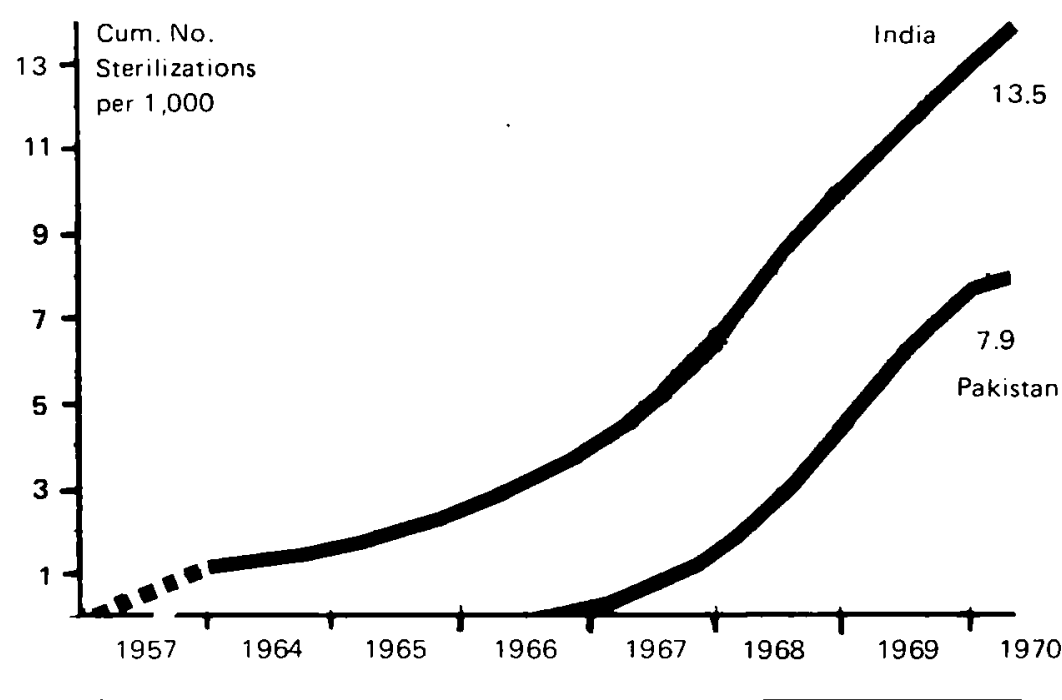

Figure 2: CUMULATIVE NUMBER OF STERILIZATIONS PER 1,000 POPULATION ${ }^{a}$ INDIA AND PAKISTAN

SOURCE: Derived from data contained in Dorothy Nortman, Population and Family Planning Programs: A Factbook (Population Council, 1970); and Depart. ment of Family Planning, Government of India, Progress of Family Planning Programme in India.

a. Calculations are based on 1969 population figures of 131.6 million for Pakistan and 536.9 million for India (1969 World Population Data Sheet, Pop. Reference Bureau). 
The operational stage of Pakistan's IUD program started about six months after India had launched its IUD effort. Notwithstanding India's brief lead during the 1965-1966 period, Pakistan has experienced a consistently higher annual rate of IUD insertions (see Figure 1). By April 1970, its cumulative rate of insertions was 22.4 per $1,000-$ more than three-and-one-half times the rate the Indian program had achieved.

The magnitude of this difference may be partially attributed to Pakistan's choice of the IUD as its exclusive contraceptive technology. While India stressed the IUD as its primary contraceptive technology, most family planning centers continued to employ a limited "cafeteria approach" whereby health personnel or patients had some choice in contraceptive method. The sterilization performance of the two countries (as shown in Figure 2) reveals a pattern, however, which challenges the assumption that Pakistan's success with the IUD was simply a result of concentrating its resources in one technology. Sterilization as a form of fertility control was introduced into the Indian national family planning strategy as early as 1957 in some parts of the country. The cumulative acceptance rate of sterilization had not climbed beyond one per 1,000 by 1964 . Sterilization was given greater emphasis, however, in the revitalized family planning program of 1965 , and its importance as a contraceptive technology continued to increase during the next four years. By April 1970, India had achieved a cumulative rate of 13.5 sterilizations per 1,000 (mainly male sterilizations or vasectomies).

Pakistan, on the other hand, did not begin to perform sterilizations until 1966, and then only on a very limited basis. Family planning leaders in Pakistan had mistakenly assumed that sterilization was not an acceptable method of fertility control in Muslim Pakistan, and they were therefore reluctant to give it programmatic emphasis. The level of performance after one year of experience with sterilization in Pakistan was so low that by the end of the year the rate of acceptance was still below that attained by India a full nine 
years earlier (see Figure 2). In a turn of events unanticipated by program administrators in Pakistan, sterilization acceptance rates in East Pakistan showed a marked upward surge. This phenomenon-in which West Pakistan participated only belatedly and to a much lesser extent-resulted in a level of monthly performance in Pakistan during the latter half of 1968 equal to the current sterilization rate of India. In less than four years, the cumulative sterilization rate for East Pakistan (13.3 per 1,000) had reached the national average for all of India. The cumulative rate for all Pakistan by March 1970, however, still lagged behind the Indian level as a result of West Pakistan's poorer performance.

In summary, India had a head start in its sterilization program, but since 1968, Pakistan has experienced the same annual rate of growth in its cumulative sterilizations per 1,000 population. Within a few months after the inception of IUD programs in both countries, Pakistan began to exhibit a consistently higher level of performance. By combining the performance rates for both IUDs and sterilizations, Pakistan still demonstrates an impressive advantage with a cumulative rate of 30.3 acceptors per 1,000 population, compared to a combined cumulative rate of 19.7 per 1,000 in India.

\section{THE SOCIAL ENVIRONMENT}

Pakistan's relatively superior program performance was accomplished, moreover, without any of the natural advantages that frequently explain variation between national family planning programs (see, e.g., Berelson, 1969). In fact, the variables that would be most likely to have predictive value favored India: the Indian government officially recognized population growth as a serious national problem and began organizing a family planning program several years before Pakistan; India had comparatively more and better trained doctors, administrators, and technical personnel to carry out its program; India had a more extensive and highly 
developed health system, including local clinics, through which to reach its target population; and, finally, the Indian population seemed more sociologically "ready" to adopt measures of fertility control.

Generally speaking, the fertility level of a society-as well as the propensity of the population to practice family planning-is highly correlated with a set of variables that are subsumed under the term modernization (for a theoretical and an empirical discussion of this point, see, respectively, Davis, 1963; Rosen and Simmons, 1971). The social and demographic variables associated with family planning adoption provide no basis for anticipating the higher level of acceptance that the Pakistan program has enjoyed. A consideration of relevant sociological characteristics shows either no significant difference between India and Pakistan or one that tends to support the hypothesis that the Indian program should have found a more responsive clientele. More specifically, India has a higher percentage of its people residing in urban areas, a higher literacy rate among women as well as men, a greater percentage of school-age children actually attending schools, and a higher ratio of roads, radios, cinemas, and energy consumption per capita. Per capita income in the two countries is roughly the same (in rupees) as are the basic demographic characteristics pertaining to life expectancy and infant mortality (data were compiled mainly from United Nations documents).

Another difference between India and Pakistan which is sociologically significant in its relationship to fertility levels and family planning adoption is the status of women in the two societies. Because Pakistan is a Muslim society, there is a greater degree of female "confinement" than in India. Muslim societies everywhere, including Pakistan, generally impose more severe restrictions upon women than do non-Muslim societies. As a result, Muslim women are less likely to engage in social or occupational activities outside the household. The greater the degree of female confinement in a society, the greater the likelihood of high fertility. Thus, 
Muslim nations generally have higher fertility rates than do non-Muslim nations and, in the same area, Muslim communities have a generally higher birth rate than do non-Muslim communities (Yaukey, 1961; Kirk, 1966). In summary, average family size in Pakistan is found to be larger than in India and is accompanied by a combination of sociological characteristics which historically have been correlated with higher fertility and less use of contraceptive techniques.

The higher parity of women in Pakistan constitutes, however, an important variable which has been linked in a different manner to family planning adoption. Research investigations have found that within nations or communities one of the best predictors of family planning adoption is the number of living children in a family (Berelson, 1969; see also Maudlin, 1965). Thus, while for a given parity, Indian women would seem more likely to adopt family planning, a somewhat greater proportion of Pakistani women are at higher parities. This factor alone, however, is not sufficient to explain the difference in the performance of the Indian and Pakistani family planning programs, especially when considered in conjunction with other sociological factors which suggest, if anything, that the Indian population would be more receptive to planned fertility control.

Emphasis on the unique or distinct characteristics of each country may obscure the fact that India and Pakistan have more in common than do almost any other two developing nations. They are both basically peasant societies and have shared the same cultural and colonial heritages for centuries. In order to discover reasons for the differing levels of success in their family planning programs, it may be more promising to explore the programs themselves and the political and administrative environment in which they operate.

\section{EARLY EFFORTS AND THE RESPONSE TO TECHNOLOGICAL CHANGE}

The mid-1960s were a critical period for family planning efforts in India and Pakistan. It was in 1965 that the two 
countries began in earnest to attack the population problem. In that year, they expanded their family planning programs, introduced the IUD as their primary contraceptive technology, and set highly ambitious performance goals. For a comparative understanding of the two programs, it is not sufficient to be concerned only with developments since 1965. The earlier experiences of the two programs shaped their later organizational characteristics and largely determined the place of family planning in the broader political and administrative systems.

India first announced a specific family planning target during the period of its Third Five-Year Plan, 1961-1966. The goal was to reduce the birth rate from a designated (although uncertain) level of 41 per 1,000 to 25 per 1,000. The third plan thus witnessed a marked acceleration in family planning efforts and expenditures, reflecting India's nominal commitment to curtail population growth, but also reflecting the characteristic gap between plans and actions. Despite the impressive increase in expenditures over the previous plan period, actual expenditures remained below fifty percent of the budgetary allocation for family planning (Demerath, 1967).

In many respects, the most important decision made by the Indian government in this period was to leave unchanged the designation of family planning as a "health" subject, a seemingly reasonable determination, but one which has had far-reaching implications for the Indian program up to the present time. Although the policy impetus for family planning in India resulted from concern over the effect of rapid population growth on economic development, family planning had been associated historically with the provision of health care for mothers and children. One of the many responsibilities of a traditional maternal and child health service was providing family planning advice, usually only upon request. Thus, when the government of India decided to move actively in the family planning field, it simply 
followed convention by viewing family planning as an aspect of health. An alternative choice could have been made at the time, but it was politically and administratively convenient to leave family planning under health. This decision has had three major consequences for the strategy, structure, and quality of performance of family planning in India.

The first consequence of the decision was that it placed the family planning program squarely in the Health Ministry. Despite the importance most developing nations attach to health, health ministries are not powerful ministries in the competition for resources within the government. The Health Ministry in India has never been headed by a person with an independent political base capable of successfully vying for financial, administrative, and political support with ministries and programs considered vital to India's economic growth such as agriculture or industrial development. Moreover, the decision to place the family planning program in the Health Ministry denied it an opportunity to acquire a distinct organizational identity, including the degree of command over its own resources associated with being an independent agency. Family planning became, instead, another claimantand not a strong one, initially-for resources within the Health Ministry in competition with the traditional health services that were more consistent with the values of the medical profession and in greater demand with the client population. Family planning was, in effect, a minor part of a weak ministry headed by doctors whose professional orientation led them to see fertility control as a personal health question rather than as a national social objective. In the assessment of John P. Lewis (1970: 18), a student of Indian development as well as former U.S. AID Mission Director,

It left family planning lodged in what, in the eyes of most observers, remains one of the weakest functional cadres in the Indian administrative system-most hesitant in effecting expeditious bureaucratic clearances, most subservient to the finance ministry overlords who pre-audit its operations-and one in which 
enervating frictions between administrative [generalists] and technical [medical] personnel already were a long standing tradition.

Furthermore, the Indian program was granted no extraordinary status and functioned under the same personnel and finance regulations as applied to all other Indian government agencies. The combination of financial and personnel constraints characteristic of the Indian system has led to lengthy delays in spending funds, an inability to hire needed personnel at an appropriate staff level, and a generally undermanned professional staff at the national level. The program conforms in its administrative structure to the conventional model found in other Indian ministries, and even the capable personnel of the Indian Civil Service, accustomed to no other administrative model or structure, failed to recognize the program's manpower deficiencies in numerous professional and administrative areas. ${ }^{6}$ Although family planning as a health subject is the constitutional responsibility of the states, the ministry could have made more significant contributions if it had been able to attract the right personnel in sufficient numbers at an appropriately high level in the organization. $^{\text {? }}$

When the IUD was introduced into the Indian Family Planning Program in 1965, it held promise of being the first contraceptive technology with a reasonable prospect of successful utilization in a low-income rural society. But by that time, family planning had become

(a) firmly entrenched in the Health Ministry, under the supervision of doctors;

(b) a program within the Health Ministry without high status, in part because of earlier dependence on inadequate technologies;

(c) a program which many officials throughout the Indian government perceived as symbolic rather than one that the government intended to implement vigorously. 
In effect, India's early start proved to be a disadvantage rather than an advantage.

In the light of subsequent developments, it might be expected that Pakistan's initial efforts in the field of family planning would stand out in sharp contrast to those of India. Actually, the earlier years of Pakistan's program parallel those of India in terms of weak commitment, an inadequate technology, a health-dominated approach, and modest expenditures. What is of greater significance is that Pakistan's program officially started in 1960, almost ten years after India's, and the program simply had less time to acquire those organizational attributes that would eventually prove to be handicaps. Between 1960 and 1964, of almost 25 million rupees committed to family planning programs by Pakistan's Second Five-Year Plan, only slightly more than 9 million rupees had been spent (Adil, 1966: 127). By most conventional measurements, Pakistan's performance in this period was not impressive: acceptance rates were low; clinics were poorly utilized; and the training of new personnel was below expectations.

A series of developments in the program eventually proved crucial, however, in enabling Pakistan's program to achieve a high performance level in subsequent years. Between 1960 and 1964, with the financial support and technical assistance of foreign agencies and universities, Pakistan established a number of centers designed to train family planning personnel, conduct population research, and carry out program evaluation.

The most significant transformation was an outgrowth of Pakistan's thorough involvement and participation in the field-testing and evaluation of the IUD. Pakistan's relationship to the worldwide program of the IUD evaluation stands in contrast to India's relative detachment. Pakistan followed up its experimental phase of the program by organizing a large-scale "demonstration" to disseminate the new technology. Indicative of the determination and even optimism 
that began to permeate the program, the Commissioner of Family Planning, Enver Adil (1965), proclaimed that "family planning is essentially [an] administrative and not a clinical program."

At the time of the introduction of the IUD in Pakistan in 1964, the Pakistani family planning program, while in the Ministry of Health, had not been there long enough to become an institutionalized component of it. Unlike India, Pakistan's brief experience with conventional contraceptive technologies prior to the IUD had not induced in the program a pervasive atmosphere of pessimism or skepticism. With the advent of new technology, it thus would be relatively easier in Pakistan to detach the program from the Health Ministry and reorganize it in a manner that would be compatible with the IUD as a method of family planning.

Based on the optimism of initial reports of the efficacy of the IUD, and with the strong support of President Ayub, plans were formulated for the National Family Planning Scheme to commence in July 1965. During the year preceding the inauguration of the new scheme, expenditures far in excess of all previous family planning funding levels were utilized, and many more personnel were trained and hired to prepare for the major effort. At that time, the program was organized as an autonomous entity only nominally within the Ministry of Health, Labour, and Social Welfare. Since then it has been independent for administrative purposes from the health services and has been granted an extraordinary degree of freedom in controlling its own budget and personnel policies. The Family Planning Council has been authorized to hire its own personnel without going through the lengthy procedures to which other agencies are subject and to establish a salary structure for its employees higher than that generally paid government servants. The employees of the family planning organization have never been brought into the conventional government services; they have enjoyed the benefits of employment and, for some, a 
higher level of income, but they can also be more easily dismissed than regular civil servants. The combination has been a strong incentive to effective performance.

\section{STATE AND DISTRICT-LEVEL ADMINISTRATION}

The second major consequence of India's decision to declare family planning a health subject was that it became the primary responsibility of the Indian states rather than of the central government. The Indian Constitution provides for a federal system and specifies the subjects for which the states are responsible-one of which is health. Consequently, the central government in New Delhi has been severely limited in the actions it can independently carry out with regard to family planning on a national level. The central government cannot require the states to implement family planning programs, nor can it hire the requisite personnel to work in states that show little initiative on their own. It can only make funds available, offer to train personnel, and provide guidelines for action; the actual implementation of the program is dependent upon the willingness of the states to act, and the states have not been uniformly disposed to accept family planning as a high-priority program. Thus, the center may appropriate funds, but these appropriations may be underspent by the states. The center may conduct research on various contraceptive technologies and make recommendations, but the states may ignore these recommendations and utilize any family planning method they prefer.

Finally, although the district is probably the critical level of government for the family planning program, officials at the central Ministry of Health have been obliged to work through the states in their dealings with the districts, rather than render advice, support, and service to the districts directly. Furthermore, the Family Planning Officer assigned to a district is largely dependent on the staff and facilities 
under the supervision of the District Health Officer, a medical doctor, and, consequently, the conflicts-and advantages-of the organizational integration of health and family planning obtain at all levels of the program.

Pakistan's system has been far more simple, direct, and semmingly effective for purposes of carrying out a family planning program. Instead of being required to respect the constitutional powers of seventeen diverse states, the Central Family Planning Council has had to be concerned with only two provinces, both of which have been highly responsive to its direction. Although the provinces have had legal authority over the programs, they have been, in effect, cooperative instruments of a unified program, not only in accepting policy direction, but also in appropriating funds.

Under President Ayub, the Pakistani program introduced a significant degree of decentralization at the district level in order to permit flexibility in responding to local needs, a feature of the program noted and endorsed by the UN evaluation team in 1969 (United Nations, 1969b: 22). The nominal head of family planning in each district is the Deputy Commissioner, who serves as chairman of the District Family Planning Board. In Pakistan, as in India, the Deputy Commissioner is by far the most powerful administrative position within a district. The Deputy Commissioner has an authoritative hand in almost every governmental program carried out within his district: he can give high priority to certain programs and ignore others, and he is a member of the nation's most prestigious administrative cadre. His promotion and future depend to a great extent on how his superiors evaluate him in an annual confidential report. As one of the responsibilities assigned to the Deputy Commissioner is family planning, the director of the national program has the authority to include in a Deputy Commissioner's annual confidential report an evaluation of his work in carrying out the district family planning program. ${ }^{8}$ As a result, the program at the district level was administratively 
supported as well as led by the Deputy Commissioner, who assured coordination with other ongoing programs in the district. Pakistan's program leadership could thus make decisions relative to such matters as personnel, finances, contraceptive technology, and local organization, and be reasonably confident that the two provinces as well as subunits of government would attempt to implement these decisions. Unlike the Indian family planning program, Pakistan's program was able to maintain regular and direct relations with the districts. District and lower-level officials recognized that Enver Adil, Ayub's Commissioner of Family Planning, functioned under a powerful presidential mandate, which greatly enhanced his influence in the districts. In addition, as a senior member of the Civil Service of Pakistan, Adil was often dealing with more junior members of the same elite administrative cadre.

Finally, the task of program direction was facilitated by a management information and feedback system that alerted the leadership to problems and deficiencies in program implementation. The national ministry had established a Central Evaluation Unit within each province which performed detailed and technical examinations of each district's family planning program. This procedure permitted the head of the national program to obtain directly from the local level certain types of information significant for policy and managerial purposes. Each province, moreover, maintained a research complex which served as an additional source of information about program activities. The national government also sent an inspection team to visit each district in Pakistan on a quarterly basis. These visits lasted for four or five days at a time and involved an evaluation of the family planning program with attention to the program's relationship to other administrative and developmental programs in the district. Both the evaluation units and the inspection teams were important ways by which Commissioner Adil "kept on top of developments in each district." 9 


\section{DELIVERY OF FAMILY PLANNING SERVICES}

A third consequence which followed from India's initial decision to declare family planning a health subject was that the program was organized in conjunction with its health care delivery system. Most contraceptive technologies require the services of medical personnel and also require a high and sustained level of motivation on the part of the user. Under these conditions, the Indian family planning program would have been expected to build an organization with a significant "outreach" component-extension agents, field workers, health educators-and a strong communication and information section. In its early years, however, instead of utilizing outreach techniques or the extension approach, the Indian program depended on a strategy of attracting clients by offering medical and contraceptive services at an expanded number of health clinics serving in a dual capacity as family planning clinics. With a superior contraceptive technology and a population motivated to curtail its fertility, this clinic system would have been appropriate. These conditions did not prevail, however, and the clinic system as it was then implemented in India was manifestly inadequate.

In 1963, the government attempted to reorganize the program in an effort to "emphasize extension education, greater availability of contraceptive supplies, and less dependence upon the traditional clinical approach" (Demerath, 1967: 184). India's failure to implement this new plan was underscored in 1965 by two different evaluation reports, one by a United Nations (1966) team, and the other by an evaluation group of the Indian Planning Commission (1965). In subsequent years, the program continued to rely mainly upon the existing health care system to administer and implement family planning in addition to the other services it was already performing.

Pakistan's program, although once part of the health system, has avoided exclusive or primary dependence on the 
health services, while at the same time utilizing the health structure to achieve its goals. No less than the Indian family planning program, the Pakistani program has also required the services of medical personnel and health clinics. ${ }^{10}$ Rather than integrating the administrative aspects of family planning with health, however, Pakistan has vested authority and responsibility for the program in a more dynamic and independent structure. ${ }^{1}$ As a result, the program can capitalize on the special resources of the health services by providing them with funds to carry out family planning activities. The program, however, is not exclusively dependent on the health services: it can work out similar financial arrangements with other governmental as well as nongovernmental agencies to perform other functions; it can compensate and utilize private physicians, indigenous midwives, and various paramedical personnel for rendering family planning services; and it can grant monetary rewards on almost a piecework basis to personnel, including those already employed by the government, for their contributions to the program.

If the programmatic decisions and organizational arrangements described in the preceding pages explain the qualitative differences between the two programs, it seems legitimate to ask why India did not make similar decisions and develop a comparable organization. Why did India designate family planning as a health subject? Why did India depend on its health delivery system rather than taking advantage of alternative structures and personnel when possible? Why did India not find more expeditious and efficient ways of adding money and personnel to its family planning program? These questions cannot be answered by attributing the Pakistan formula to superior administrative know-how, to a higher level of demographic competence, or even to greater wisdom on the part of Pakistan's political and administrative leaders. India surely equalled and perhaps surpassed Pakistan in those human resources needed to carry out developmental programs, including family planning. 
The answer should be sought elsewhere-namely, in the politics and national development strategies that prevailed in the two countries.

\section{POLITICS AND THE PLANNING PROCESS}

Despite variations in the economic models and the sectoral priorities adopted by India and Pakistan, they have both established rapid economic growth as their paramount objective. The pervasive scarcity in both countries serves as a constant reminder to politicians, planners, and bureaucrats that without economic growth the eloquently expressed ideals and aspirations of their leaders will remain beyond reach of the people. Reflecting this need, each five-year plan has set forth a series of development goals and spelled out economic programs and policies designed to achieve them. In this sense, then, India and Pakistan share common development strategies. The difference in development strategy between India and Pakistan is not a result of planning goals as much as a result of the planning process and its relationship to each country's political system.

Policy formulation in India is subject to the restraints and demands of diverse groups and elements in the society. Economic development objectives are tempered by the intervention of the political sector, which requires them to reflect values other than economic growth such as social welfare and more equal distribution of wealth. In effect, economic planning in India is politicized; it is subject to the public scrutiny, debate, bargaining, and compromise that characterize Indian politics. While the Indian government makes no pretense that plans are formulated by popular referendum, it has not attempted to isolate the planning process from the pressures of democratic political life. A. H. Hanson (1968: 26), an astute analyst of Indian planning, confirms this view: 
The techniques of planning that the [Planning] Commission employs. which involve wide consultation and extensive publicity. provide opportunities for the effective exertion of a variety of organized pressures. This is advantageous to the extent that the pressures can be absorbed, or that the people exerting them can be persuaded to accept compromises. It is disadvantageous to the extent that the Commission is compelled to diverge from economic rationality. to raise hopes doomed to frustration, and to seek fictitious "agreement."... Both the advantages and disadvantages. however, are the essence of any planning in a political order based on conciliation.

The Indian political system has held together despite the severity of its nation-building crises because conciliation has become institutionalized at critical points in the system. The Indian political system continues to function and retain its democratic character because it has recognized its own limitations and has not strained its capacity to mobilize for development at the risk of violating or alienating major segments of the society. State governments, parliamentary bodies, and opposition parties must be reckoned with in the formulation of economic plans and development strategy. This, in part, explains the continued legitimacy accorded the Indian political system by its people, as well as the rate and direction of Indian development.

Pakistan's development strategy and the process by which it is formulated is also an expression of the country's politics and influence patterns. But politics and the distribution of influence in Pakistan differ from India. To appreciate these differences and their origins, consideration must be given to Pakistan's political history since independence in 1947. which, compared to India, has been more erratic, disjointed, and susceptible to extraconstitutional political upheaval. General Ayub Khan's seizure of political power in 1958 signified for many that for the first time Pakistan had a political leader strong enough to get things done, or, as Ayub himself phrased it, "to clear up the mess" (Pye, 1966: 369). 
General Ayub's task of providing Pakistan with firm political leadership and moving the nation into a more promising development orbit was facilitated by the nation's political chaos, the pervasiveness of economic stagnation, and the endemic dissatisfaction of the population. In reviewing the state of affairs in 1958, Gustav Papanek (1967:6) states that the new government "was sure of a long lease on political life [and] was strong enough to carry out policies that offended particular groups and were unpopular in the short run."

Although Ayub sought to create a basis of legitimacy for his seizure of power through a new constitution and a popular election, the real basis of his support was mass disenchantment with the old regime and the hopes his leadership inspired. The takeover in 1958 was seen as a classic case of military intervention by a modernizing military elite, led and epitomized by General Ayub. At a minimum, "military modernizers" are expected to effect orderly change and manage the affairs of the nation in a way conducive to modernization. The basis of legitimacy for Ayub, then, depended upon what Lipset has called effectiveness, and the meaning of effectiveness in most developing nations is economic growth. ${ }^{12}$

The new government under Ayub had no ready-made development strategy, but it did possess sufficient political strength to assure itself an opportunity to learn from its own mistakes and identify domestic and foreign talent that might enable it to energize the nation's economy. "The government," in the words of Papanek (1967: 6), "made economic policy a central concern, since it had justified its take-over largely in terms of economic mismanagement by previous governments." In the candid language of one of the government's former chief economists, Mahbub-ul-Haq (1971: 2), Pakistan

took the basic decision of devoting all the energies of the system towards a faster pace of economic development and to forget 
about the issues of more equitable distribution or a more democratic system of economic organization. The first priority was growth; the other questions will come later.

If India's development strategy could be described as more or less politicized, then it is appropriate to describe Pakistan's as "depoliticized." Pakistan was able to adopt a development strategy that subordinated-if not ignored-questions of social welfare, distribution, and equity to the primary objective of rapid economic growth. This was possible because the process of planning and economic policy formulation did not occur in a political arena where organized groups and political parties concerned about such issues as distribution and equity had access or influence. "The Planning Commission was isolated from the political process-its only mandate being to devise policy for yet a faster growth rate" (Haq, 1971). It would be more accurate to postulate that planning was insulated from the free play of group politics or from the democratic political process. If large industrialists, landowners, and entrepreneurs did not influence economic decisions and plans directly, it was because they found those plans congenial to their interests or they had access to other, less overt channels of influence (for further analysis of Pakistan's approach to economic development and the role of the private sector, see a critical and perceptive article by Nulty and Nulty, 1971).

\section{THE POLITICAL ENVIRONMENT OF THE FAMILY PLANNING PROGRAMS}

Khalid B. Sayeed (1967: 102) has characterized Pakistan's political system under Ayub as a constitutional autocracy:

Ever since he seized power, he had consistently argued that parliamentary democracy is not likely to work in Pakistan where literacy is so low and where the people are not informed or mature enough to use their votes to support certain national policies or programs. 
As a consequence of Ayub's low assessment of parliamentary democracy and his power to translate his ideas into action, Pakistan's political system came to be comprised of a strong executive, weak parliament, weak provinces vis-à-vis the central government, a political order that muffled rather than facilitated the articulation of political demands, and a leadership committed to achieving national development goals without great regard for ideological considerations or popular sentiments.

Under the Ayub government, Pakistan adopted policies and organized programs designed to accelerate economic growth, and, in contrast to India at that time, selected the type of industrial investment that has a much shorter gestation period and a much lower capital-output ratio (Mason, 1966: 6-7). As the Ayub government formulated its policy for long-range economic growth, it took congnizance of population factors. In 1959, Ayub had declared that "the menace of over-population and rapid rate of population increase exists in most underdeveloped countries, and a big concentrated drive is necessary to educate the people about the evils of overpopulation." 3 Within a few years, the government considered population control an essential ingredient of its economic policy. Population control was approached with the same determination and energy that characterized Pakistan's other economic programs.

With the active support of President Ayub, Pakistan's family planning program was vested with the power to bypass or ignore many of the conventional political, administrative, and social restraints that impede family planning programs in other nations. The major responsibility of the family planning program in Pakistan has been managerial, a difficult responsibility, yet one that is restricted largely to developing an effective system to promote and deliver contraceptives to potential adopters. It has been able to use its time, energy, and resources to train personnel and to improve its logistics, its supply system, and its evaluation system. The program has 
had the authority of the President behind it, reinforced by the considerable abilities of Pakistan's planners and technicians, and it has had the power and authority to utilize money as an additional incentive to government servants and others to help advance the program.

India's political leadership has not shown the same level of support for family planning as evidenced by Ayub, partly because economic growth, population control, and other developmental programs in India are viewed as subordinate to the larger efforts of nation-building. ${ }^{14}$ Population control in India has neither the strong political constituency nor the autocratic executive leadership which would be necessary to give it the dynamism of Pakistan's family planning program. The Prime Minister of India occupies a weaker executive position, parliamentary democracy is genuine, Indian federalism provides its seventeen states with extensive powers vis-à-vis the center, and the ability of the Indian government to direct the nation is limited by political parties and divergent groups which have been able to articulate their demands within the political system.

The Indian political context has not permitted the family planning program to confine itself to the delivery of service. While the family planning program has certainly not ignored this central role, the program has not been able to pursue it with the single-mindedness of purpose of the Pakistani program. It has been required to invest much of its time, energy, and resources in winning over other authoritative institutions within India. Program leaders in the central government, first of all, must try to deal with reluctant states headed by chief ministers, finance ministers, or health ministers who do not necessarily attach a high priority to family planning. The leaders of the Indian family planning program have had to convince various voluntary associations, regional groups, caste groups, economic interests, religious groups, and professional organizations that the family planning program, and fertility control itself, would not under- 
mine their relative power, status, and economic position in the society. For example, Pakistan has been able to use young women to insert the IUD after a relatively brief training period, a practice which has not evoked mass opposition from Pakistan's medical association. Pakistan's doctors do not have an independent medical association with the organized strength of the Indian medical association, nor would the Pakistan government be predisposed to respond to their influence. The contrasting sensitivity of the Indian government to significant groups within its own polity has precluded the family planning program from violating the professional norms of the medical profession by employing paramedical personnel for similar roles.

The task of eliciting the cooperation and support of authoritative institutions and state and local political leaders has been made more difficult by the inherent lack of political appeal family planning holds for politicians. In India, as in most societies, the short-run, parochial political rewards of family planning are negligible, and, in some cases, are outweighed by the political risks and liabilities. Although government investment in family planning programs in the developing nations may have a higher cost-benefit ratio than any other investment available to government, the benefits from a national family planning program are long-range, hard to demonstrate (except in statistical terms), and generally devoid of the visible impact of a new bridge or road in a community. A politician or an administrator has little prospect of receiving acclaim from his constituents for helping to prevent the birth of $x$ number of Indian or Pakistani children. Without inherent political appeal and without being able to count on the continued and active support of political leaders, Indian family planning administrators have had to devote organizational resources to gaining the cooperation and support of governmental units and groups rather than delivering services. 


\section{THE ROLE OF FOREIGN ASSISTANCE}

Foreign assistance has been an important component of Indian and Pakistani development programs; compared to India, however, Pakistan has enjoyed a favored status as a recipient of foreign aid, especially from the United States. Between 1966 and 1968, a typical period, Pakistan received $\$ 480$ million and India received $\$ 1,191$ million in net official receipts (nonmilitary) from bilateral and multilateral donors, making them the two highest recipients in the world (OECD, 1970: 318). On a per capita basis, however, aid for the same period totaled $\$ 3.96$ for Pakistan as opposed to $\$ 2.32$ for India (OECD, 1970: 315 ).

Pakistan's favored status was initially a consequence of the country's serious economic plight in the late 1950s, when General Ayub assumed power. A large infusion of foreign aid seemed essential to the country's unity and stability. Moreover, Pakistan's domestic and foreign policies under Ayub were congenial to the United States. Unlike India, where government controls and the public sector of the economy were emphasized, Pakistan adopted policies that gave considerable latitude and support to the private sector. Whereas, in international relations, India adopted a policy of neutrality, Pakistan aligned itself with the United States and the West and became an important member of CENTO and SEATO. Later, Pakistan strengthened its credentials as a recipient by demonstrating under Ayub a capacity to utilize such assistance effectively. Pakistan, in contrast to India, was highly receptive to the advice of donor nations and showed little of the national sensitivity so much evident in India where foreign advisers and experts were regarded as a necessary form of external interference in Indian affairs.

Foreign aid has played a critical role in the Indian and Pakistani population programs by providing financial and technical inputs which have had the effect of freeing domestic resources that might not otherwise have been as 
readily available for family planning purposes. The reason foreign aid has had this effect, especially in the initial stages of the two programs, is that organized efforts at limiting population growth are largely untried and experimental. As was pointed out earlier, even when family planning programs are successful, the returns are delayed, invisible, and, in the short range, of questionable political value. It is easier for a nation, therefore, to employ foreign funds earmarked for family planning as venture capital than to divert scarce domestic resources from more conventional development projects.

As with foreign aid generally, Pakistan's family planning program has been a proportionately greater beneficiary of outside assistance. Despite a population roughly one-fourth the size of India's, Pakistan received $\$ 6.8$ million from fiscal 1966 through fiscal 1968 for its family planning program compared to $\$ 6.3$ million for India's, according to figures compiled by Warren Robinson (1969: 147). Pakistan demonstrated early that it was prepared to tackle the population question with a level of energy and determination that was absent in India and was more willing than India to take advantage of the advice and skills of foreign technical assistants. These factors in turn became a justification for the greater interest shown by donor nations in the Pakistan program.

\section{CONCLUSION}

In the period covered by this analysis, Pakistan was more successful than India in pursuing economic development as well as population control, but was the less successful of the two in its political development. If India is susceptible to the accusation that it has made too many concessions to politics, Pakistan is even more vulnerable to the opposite accusation that it has not been sensitive enough to the needs of the political sector. Guided by the philosophy that economic 
growth is not only its own reward but is a nation's long-range guarantee of political stability, Pakistan ordered its political life and its policies to maximize its capacity to generate and sustain rapid economic growth. While the private sector was given a free hand, the distribution crisis worsened; while issues of economic location were resolved in an economically "rational" fashion, geographical disparities were intensified; while the classical model of subsidizing urban and industrial development at the expense of the agricultural sector was pursued, rural dissatisfaction grew; while entrepreneurship was rewarded, the intelligentsia rebelled (see Nulty and Nulty, 1971). These were difficult policy decisions for Ayub and his government, as the outcomes could clearly lead to the loss of vital political support. Yet, with the encouragement of both domestic and foreign economic advisers, Ayub opted for economics at the expense of politics, a choice which ultimately led to political collapse and a new cycle of military intervention in Pakistan's politics. ${ }^{15}$

India, on the other hand, has shown considerable commitment to Western parliamentary government as well as ideological dedication to socialism and egalitarianism. Much more indigenous to India has been its commitment to conciliation and bargaining as a means of resolving internal conflict. These characteristics are reflected in the country's competitive party system, the absence of military intervention in politics, the continuation of a free press, the constitutional as well as de facto strength of the states, and a range of significant as well as symbolic policies adopted by the government in every area of social life. While India has not been economically stagnant, at no time has it shown the political capacity or the will to go all-out for rapid economic growth, especially if such growth would necessitate major compromises for the political system.

The experiences and relative performance of India and Pakistan in administering national family planning programs are functionally related to each nation's politics and develop- 
ment strategy. Considerable evidence has been presented in this paper indicating that the properties of a nation's political system and its development policies are important determinants of program performance. The combination of politics and development strategy that may seem highly productive for one field of development, however, may not be functional for another field. For example, in contrast with family planning, consider the impact of these factors on community development, where India has been more successful than Pakistan (see, e.g., Rahman, 1967).

Paradoxically, the strength of Pakistan's family planning program is closely associated with factors that have spelled disruption and breakdown for Pakistan's political development. The comparative weakness of India's effort to control population growth is linked to the viability of its democratic political institutions as well as to its less impressive performance in achieving more rapid economic growth during the 1960 s.

\section{NOTES}

1. Earlier predictions of U.S. demographers had also underestimated the degree of population growth (see Coale and Hoover, 1958). The reputation of Coale and Hoover's book is already well established as a seminal work in the field. Simmons' recent book is highly instructive not only for its analy sis of the Indian program, but also for its general treatment of family planning as a form of economic investment in developing nations generally.

2. Although Lewis presents evidence limited to India, his information on this point is equally applicable to Pakistan.

3. India had supplemented the conventional array of mechanical and chemical contraceptives by making available in some areas both male and female sterilization. Neither country offered the Pill through its govemment-sponsored program because of concem over cost, side-effects, and the belief that the regimen of the one-a-day Pill would not be followed by most women.

4. In 1969, when a team of experts from a United Nations evaluation mission reviewed the Indian family planning program, they indicated that "the optimistic view of the IUD generally prevailing at that time was largely responsible for their [subsequent problems] not having been fully appreciated. 
Lack of an effective evaluation mechanism in the programme of promptly analyzing such problems aggravated the difficulties" (United Nations, 1969a: 6).

5. Reports on several studies on age, parity, or IUD retention of family planning adopters in India and Pakistan have appeared in Population Council (1963-1970). See issues numbered 1, 8, 18,31, 35, 39, 47, and 56. The judgment attributed to "firsthand observers" is based on numerous discussions the author has had with representatives and experts from the United States and international agencies and universities.

6. In his analysis of Indian public administration, A ppleby (1956) elaborates on the stifling effect of the system's bureaucratic controls.

7. Illustrative of some of the functions the Central Ministry of Health could have performed were more regular high-level liaison with the states, with foreign and international donor agencies, and with private and voluntary organizations and associations throughout India who are potentially capable of contributing in some way to India's family planning effort. The family planning program eventually did assign staff to assume some of these responsibilitics; even then, those assigned to these roles were not of sufficient status or high cnough in the system to carry out their responsibilities without referring an inordinate number of questions to their administrative superiors.

8. This information is taken from a personal interview conducted with Dr. Nafis Sadik, the Director General of the Pakistan Family Planning Council, in Ann Arbor, Michigan, on May 18, 1971. Significantly, in the few states of Indja, such as the Punjab and Madras, where similar responsibility was imposed upon the deputy commissioner, the family planning program scored higher grades in terms of IUD insertions and sterilization operations performed.

9. This information is also taken from an interview with Dr. Nafis Sadik.

10. The UN/WHO evaluation report on Pakistan pointed out that the framework of the health services "reached only about $10 \%$ of the rural population." The report also suggested that the underdeveloped health services of Pakistan were one of the factors which induced the government to establish a separate family planning organization (United Nations, 1969b: 43).

11. Although the thesis presented here attributes much of the success of Pakistan's program to administrative separation from the health services, the combined UN/WHO evaluation mission was somewhat critical of this separation (United Nations, 1969b: 47-50). The position of the UN/WHO mission reflects a consistent view of WHO in favor of treating family planning as an integral aspect of health.

12. Lipset (1960: 82) states that "prolonged effectiveness over a number of generations may give legitimacy to a political system. In the modern world, such effectiveness means primarily constant economic development." For an interesting discussion of this question, see Ilchman and Uphoff (1969: esp. 111-114).

13. Indian leaders have often made similar pronouncements, but in my judgment, Ayub was strongly committed to this position, as his subsequent behavior indicated.

14. Simmons (1971: 183) concludes that despite the emphasis given to population control in written statements emanating from the Indian Planning Commission, the Commission actually attached low salience to population. He 
advances two fundamental reasons for the discrepancy between words and action: "First, although per capita income has been indicated to be the major goal of Indian economic planning, it seems likely that the major operational goal is total national income. Second, the early plans were based on demographic and economic models which did not leave any role for population policy." These findings suggest additional reasons why Indian planning might have been more easily diverted from population control as a result of political considerations.

15. At the outset of his study on the role of the military, Janowitz (1964: 1) observes: "Those organizational and professional qualities which make it possible for the military of a new nation to accumulate political power, and even to take over political power, are the same as those which limit its ability to rule effectively."

\section{REFERENCES}

ADIL, E. (1966) "Pakistan," in B. Berelson et al. (eds.) Family Planning and Population Programs. Chicago, 1l.: Univ. of Chicago Press.

-- (1965) Family Planning Scheme for Pakistan. Karachi: Government of Pakistan Ministry of Health.

APPLEBY, P. (1956) Re-Examination of India's Administrative System. Delhi: Government of India, Cabinet Secretariat.

AYUB, M. (1959) Address to the Food Conference in Lahore, January.

BALFOUR, M. (1962) "Chairman's report of a panel discussion on comparative acceptability of different methods of contraception," pp. 373-386 in C. V. Kiser (ed.) Research in Family Planning. Princeton, N.J.: Princeton Univ. Press.

BEAN, L. L. (1971) "Pakistan's population in the 1970's: certainties and uncertainties." Presented at the Annual Meeting of the Association for Asian Studies. Washington, D.C.. March 30.

BERELSON, B. (1969) "Where we stand," pp. 341-386 in S. J. Behrman et al. (eds.) Fertility and Family Planning: A World View. Ann Arbor: Univ. of Michigan Press.

$--(1966)$ "KAP studies on fertility," in B. Berelson et al. (eds.) Family Planning and Population Programs. Chicago, Ill.: Univ. of Chicago Press.

COALE, A. and E. M. HOOVER (1958) Population Growth and Economic Development in Low-Income Countries. Princeton, N.J.: Princeton Univ. Press.

DAVIS, K. (1963) "The theory of change and response in modern demographic history." Population Index 29: 345 366.

DEMERATH, N. J. (1967) "Can India reduce its birth rate? a question of modernization and organizational capacity." J. of Social Issues 23 (October): 179-194.

FALCON, W. P. and C. H. GOTSCH (1968) "Agricultural policy and performance in the Punjab: a comparative study for India and Pakistan." Economic Development Report 96, Harvard University Center for International Affairs. 
HAGEN, E. E. (1962) On the Theory of Social Change. Homewood, IU.: Dorsey. HANSON, A. H. (1968) "Power shifts and regional balances," in P. Streeten and M. Lipton (eds.) The Crisis in Indian Planning: Economic Policy in the 1960's. London: Oxford Univ. Press.

HAQ, MAHBUB-UL- (1971) "Pakistan's economic choices for the 1970's." Presented at the Annual Meeting of the Association for Asian Studies, Washington, D.C., March 30.

HARDEE, J. G. and A. P. SATTERTHWAITE (1970) "Pakistan." Country Profiles. (March).

ILCHMAN, W. F. and N. T. UPHOFI: (1969) The Political Economy of Change. Berkeley: Univ. of California Press.

Indian Planning Commission (1965) Evaluation of the Family Planning Programme. Government of Indian Programme Evaluation Organisation.

JANOWITZ, M. (1964) The Military in the Political Development of New Nations. Chicago, Ill.: Univ, of Chicago Press.

KIRK, D. (1966) "Factors affecting Moslem natality," pp. 561-580 in B. Berelson et al. (eds.) Family Planning and Population Programs. Chicago, IIl.: Univ. of Chicago Press.

LEWIS, J. P. (1970) "Population control in India." Population Bull. 26 (November 5).

LIPSET, S. M. (1960) Political Man: The Social Bases of Politics. New York: Doubleday.

McClelland, D. (1961) The Achieving Socicty. Princeton. N.J.: D. Van Nostrand.

MASON, E. S. (1966) "Economic development in India and Pakistan." Occasional Paper in International Affairs 13. Harvard University Center for International Affairs.

MAUDLIN, P. (1965) "Fertility studies: knowledge, attitude, and practice." Studies in Family Planning (June).

NULTY, T. and L. NULTY (1971) "Pakistan: the busy bee route to development." Trans-action 8 (February): 18-26 ff.

OECD (1970) 1969 Review: Development Assistance-Efforts and Policies of Members of the Development Assistance Committee. Paris.

PAPANEK, G. (1967) Pakistan's Development: Social Goals and Private Incentives. Cambridge, Mass.: Harvard Univ. Press.

PYE, L. W. (1966) "Party systems and national development in Asia," in J. La Palombara and M. Weiner (eds.) Political Parties and Political Development. Princeton, N.J.: Princeton Univ. Press.

RAHMAN, A. T. R. (1967) "Theories of administrative and political development and rural institutions in India and Pakistan." Southeast Asia Development Advisory Group Papers on Development and Development Policy Problems 23.

ROBINSON, W. (1969) "A cost-effectiveness analysis of selected national family planning programs." Pennsylvania State University. (mimeo)

ROSEN, B. C. and A. B. SIMMONS (1971) "Industrialization, family and fertility." Demography 8: 49-70. 
ROSTOW, W. W. (1960) The Stages of Economic Growth. London: Cambridge Univ. Press.

SAYEED, K. B. (1967) The Political System of Pakistan. Boston: Houghton Mifflin.

SEGAL, S. J., A. L. SOUTHERN, and K. D. SHAFER [eds.] (1964) Intrauterine Contraception: Proceedings of the Second International Conference, New York City, 2-3 October, 1964. Amsterdam: Excerpta Medica International Congress.

SELTZER, W. (1970) "Measurement of accomplishment: the evaluation of family planning efforts." Studies in Family Planning 53 (May): 9-15.

SIMMONS, G. B. (1971) The Indian Investment in Family Planning. New York:

Population Council.

United Nations (1969a) An Evaluation of the Family Planning Programme of the

Govemment of India. UN Advisory Mission, Secretariat, Document ST/SOS/ SER.R/11.

$---(1969 \mathrm{~b})$ Report on an Evaluation of the Family Planning Programme of the

Government of Pakistan. World Health Organization Advisory Mission, Secretariat. Document ST/SOA/SER.R/9.

$---(1966)$ Report on the Family Planning Programme of India. Department of Economic and Social Affairs. Document TAO/IND/48.

YAUKEY, D. (1961) Fertility Differences in a Modernizing Country. Princeton, N.J.: Princeton Univ. Press.

\section{Politics and Bureaucracy in \\ the European Community David Coombes}

A thorough and rigorous analysis of the European Economic Community, focusing primary attention on its Commission. Central to the author's discussion is the relationship of politics to administration and the need for changes in institutions to achieve political unity.

Following a brief introduction to the European Movement from which the European Community emerged, the author describes the legal, institutional, and human elements and objectives of EEC. These lead to the main part of the book: the role of the Commission in the political process of EEC. The concept of bureaucracy, drawn from the study of comparative politics and public administration, is shown to be relevant to the Community's institutional problems. The author concludes by relating his findings to the future prospects of the Com. munity and European unity in general.

Published in cooperation with P.E.P. (Political and Economic Planning). ISBN 0.8039-0037-6 $\$ 8.50$ clothbound 250 pages 